\title{
Expression of Complement Proteins C2 and Factor B in Transfected L Cells
}

David H. Perlmutter, Harvey R. Colten, Dario Grossberger, Jack Strominger, J. G. Seidman, and David D. Chaplin Divisions of Gastroenterology, Nutrition and Cell Biology, Children's Hospital, Ina Sue Perlmutter Cystic Fibrosis Research Center, Department of Biochemistry and Molecular Biology, Harvard University; Departments of Pediatrics and Genetics, Harvard Medical School, Boston, Massachusetts; and Howard Hughes Medical Institute and Department of Internal Medicine, Washington University School of Medicine, St. Louis, Missouri 63110

\section{Abstract}

Factor B and C2 are structurally and functionally similar complement proteins encoded by genes that are closely linked within the class III region of the major histocompatibility complex (MHC). In this study, restriction endonuclease digestion of cosmid DNAs isolated from an $\mathrm{H}-2^{\mathrm{d}}$ murine genomic library indicated that the chromosomal organization of these two genes was similar in mouse to that in man. To further characterize their expression, cosmid DNAs encoding human and murine factor $B$ and $C 2$ were introduced into mouse $L$ cells by DNA-mediated gene transfer. Factor B expression was demonstrated in cells transfected with either the human or the murine gene, but not in cells transfected with a control plasmid. Synthesis and secretion of factor $B$ by $L$ cells transfected with the human and murine cosmids was similar to that of human and murine cells in primary culture. An interspecies variation between human and murine factor B was identified and reproduced with extraordinary fidelity by the mouse fibroblast. In contrast, $\mathrm{C} 2$ RNA and protein were expressed by $L$ cells alone and by $L$ cells transfected with a control plasmid, as well as by $L$ cells transfected with cosmids encoding human and murine complement genes. Expression of the transferred human $\mathrm{C2}$ gene was demonstrated by the presence of a new distinct C2 RNA transcript and secretion of biologically active human $\mathrm{C2}$. These results demonstrate the similarity of organization of the murine and human class III MHC regions. Expression of the two closely linked gene products, $C 2$ and factor B, after DNA-mediated gene transfer provides a system for further analysis of regulation in both normal and deficient states.

\section{Introduction}

Factor B, of the alternative complement-activating pathway, and $\mathrm{C} 2$, of the classical complement-activating pathway, have many structural and functional similarities (reviewed in reference 1). Synthesis of factor B and C2 occurs predominantly in the liver, but also in extrahepatic mononuclear phagocytes (2). Factor B is synthesized as a single-chain $\sim 90-95,000-\mathrm{D}$ glycoprotein. Cleavage into two fragments, $\mathrm{Ba}\left(M_{\mathrm{r}} \sim 30,000 \mathrm{D}\right)$, and $\mathrm{Bb}\left(M_{\mathrm{r}}\right.$ $\sim 60,000 \mathrm{D})$, by factor $\mathrm{D}$ activates the zymogen. The carboxy terminal fragment $(\mathrm{Bb})$ combines with $\mathrm{C} 3 \mathrm{~b}$ to form the alter-

This work was supported in part by an American Liver Foundation Postdoctoral Fellowship Award, the Jane Coffin Childs Memorial Fund for Medical Research, and by the Mallinkrodt Foundation. Address Correspondence to Dr. Chaplin, Howard Hughes Medical Institute, Washington University School of Medicine.

Received for publication 19 December 1984.

J. Clin. Invest.

(C) The American Society for Clinical Investigation, Inc. 0021-9738/85/10/1449/06 $\$ 1.00$

Volume 76, October 1985, 1449-1454 native pathway $\mathrm{C} 3$ converting enzyme. $\mathrm{C} 2$ is synthesized as a single-chain $\sim 92,000-\mathrm{D}$ glycoprotein, which is also cleaved into a large carboxy terminal fragment (C2a) and a small, C2b fragment. The $\mathrm{C} 2 \mathrm{a}$ fragment then combines with a cleavage product of the fourth component, $\mathrm{C} 4 \mathrm{~b}$, to generate the classical pathway C3 convertase. Although C3 serves as substrate for both activation pathways, differences in local concentrations of the $\mathrm{C} 2$ and factor $B$ proteins may effect the relative importance of the classical and alternative pathways in initiation of the complement effector system.

By genetic linkage analysis, the genes encoding these complement proteins have been mapped to the major histocompatibility complex (MHC) ${ }^{1}$ on the short arm of chromosome 6 in humans and on chromosome 17 in mouse (reviewed in reference 3). Recently, cosmid cloning has demonstrated extremely close linkage of the human genes with the 3 -end of the $\mathrm{C} 2$ gene lying within $\sim 2,000$ base pairs of the $5^{\prime}$-end of the factor $B$ gene, and with the $C 4$ genes lying an additional $\sim 10,000$ base pairs further downstream $(4,5)$. The gene order in the human class III region is, thus, $\mathrm{C} 2$, factor $\mathrm{B}$, and two $\mathrm{C} 4$ genes. Although similar linkage of factor B and C4 genes has been shown in mouse (6), the order of the murine $C 2$ and factor $B$ genes on chromosome 17 has not been previously determined.

Despite this extensive structural and functionai similarity, and close linkage within the class III region of the MHC, there are major differences in the expression of factor B and C2 (711). In fact, both species-specific and tissue-specific differences in the expression of these two complement proteins have been demonstrated. The present study uses DNA-mediated gene transfer to introduce the genes encoding both human and mouse C2 and factor B into L cells. With the genes from both man and mouse introduced into the same genetic background, it should be possible to investigate which features of the differential expression of these genes are characteristic of the genes themselves and which are the result of differential processing by the cells in which they are transcribed. In addition, transfected $\mathrm{L}$ cells might provide a system in which to examine, both at the transcriptional and translational level, the modulation of expression of these two early acting complement proteins by mediators of inflammation.

\section{Methods}

Materials. Dulbecco's modified essential medium (DME), DME lacking methionine, Hanks' balanced salt solution, fetal bovine serum, and trypsin-EDTA solution were obtained from Gibco Laboratories, Grand Island, NY. L- ${ }^{35}$ S $]$ methionine (specific radioactivity $\sim 1,000 \mathrm{Ci} / \mathrm{mmol}$ ), $\left[{ }^{32} \mathrm{P}\right]$ deoxycytidine triphosphate (specific radioactivity $\sim 3,000 \mathrm{Ci} / \mathrm{mmol}$ ),

1. Abbreviations used in this paper: DME, Dulbecco's modified essential medium; HAT, $1.36 \mathrm{mg} / \mathrm{ml}$ hypoxanthine, $17.4 \mu \mathrm{g} / \mathrm{ml}$ aminopterin, and $388 \mu \mathrm{g} / \mathrm{ml}$ thymidine; kb, kilobase; MHC, major histocompatibility complex; PAGE, polyacrylamide gel electrophoresis; PBS, Dulbecco's phosphate-buffered saline. 
and $\mathrm{En}^{3} \mathrm{Hance}$ were purchased from New England Nuclear, Boston, MA, and ${ }^{14} \mathrm{C}$-methylated protein standards from Amersham Corp., Arlington Heights, IL. Other reagents included sodium deoxycholic acid, ethidium bromide, 2-mercaptoethanol from Sigma Chemical Co., St. Louis, MO, Triton X-100 from Mallinckrodt Inc., St. Louis, MO, SDS and acrylamide from Bio-Rad Laboratories, Richmond, CA, IgG-Sorb from Enzyme Center, Cambridge, MA, leupeptin from Peptide Research Institutes, Osaka, Japan, pepstatin A from Calbiochem-Behring Corp., La Jolla, CA, agarose from FMC Corp., Rockland, ME, and 37\% formaldehyde solution from Fisher Scientific Co., Pittsburgh, PA. Antisera included sheep anti-human C2 from Seward Laboratories, London, England, sheep anti-human $\mathrm{C} 2$ from Miles Laboratories Inc., Elkhart, IN, and goat antihuman factor B from Atlantic Antibodies, Scarborough, ME. Restriction enzymes were obtained from New England Biolabs, Beverly, MA, or Bethesda Research Laboratories, Gaithersburg, MD, and used according to manufacturers instructions. Plasmid pBR-TK (herpes simplex virus thymidine kinase in pBR327) was a gift from Dr. Lynn Enquist, Dupont, Wilmington, DE.

\section{Methods}

Preparation and screening of cosmid libraries. The preparation of the murine cosmid genomic library $\left(\mathrm{H}-2^{\mathrm{d}}\right)$ and initial isolation of clones has been described previously (6). The murine cosmid cluster was extended using cosmid walking procedures as described (6). The human cosmid genomic library was constructed from DNA isolated from the cell line JY, using methods similar to those used for the murine library except that the insert DNAs were size fractionated by sucrose gradient centrifugation before ligation to the cosmid vector pJB8. The human cosmid library was screened according to the method of Hanahan and Meselson (12) using as a probe the human cDNA insert of plasmid pBfA28 (13), ${ }^{32} \mathrm{P}$-labeled by nick-translation (14). Cosmid DNA was isolated according to the method of Ish-Horowicz and Burke (15).

Cell culture and biosynthetic labeling. Mouse $\mathrm{L}$ cells (TK-) and HepG2 cells were maintained as monolayers in $75-\mathrm{cm}^{2}$ tissue culture flasks with DME containing $10 \%$ heat-inactivated fetal bovine serum as previously described $(16,17)$. Mouse peritoneal macrophages were harvested and adhered to plastic tissue culture wells as previously described (7). For biosynthetic labeling, cells were subcultured into $35-\mathrm{mm}$ dishes, incubated in serum-free medium for $12 \mathrm{~h}$, and rinsed three times with DME lacking methionine. $\mathrm{L}-\left[{ }^{33} \mathrm{~S}\right]$ methionine, $500 \mu \mathrm{Ci} / \mathrm{ml}$ of DME lacking methionine, was added and cells incubated at $37^{\circ} \mathrm{C}, 5 \% \mathrm{CO}_{2} / 95 \%$ air for time periods ranging from $30 \mathrm{~min}$ to $24 \mathrm{~h}$ (pulse period). At the end of the pulse period, unlabeled methionine-containing medium was then added in 200-1,000-fold excess for time periods up to $6 \mathrm{~h}$ (chase period). At specified intervals, culture medium was harvested and monolayers rinsed six times, solubilized in $1 \%$ Triton X-100, $0.5 \%$ deoxycholic acid, $10 \mathrm{mM}$ EDTA, $2 \mathrm{mM}$ phenylmethylsulfonyl fluoride, leupeptin, and pepstatin A, $100 \mu \mathrm{g} / \mathrm{ml}$ each, in Dulbecco's phosphate-buffered saline (PBS), pH 7.6, and subjected to two freeze-thaw cycles. Supernatants and lysates were clarified by centrifugation at $15,000 \mathrm{~g}$ for 5 and $30 \mathrm{~min}$, respectively, and stored at $-70^{\circ} \mathrm{C}$. Trichloroacetic acid-precipitable protein was determined as previously described (18).

Immunoprecipitation and SDS-polyacrylamide gel electrophoresis (PAGE). For staphylococcal protein A immunoprecipitation, 100-300$\mu \mathrm{l}$ aliquots of cell lysate or medium were incubated overnight at $4^{\circ} \mathrm{C}$ in an equal volume of PBS containing $1 \%$ Triton X-100, $0.5 \%$ SDS, and 5 $\mathrm{mg} / \mathrm{ml}$ bovine serum albumin, with aliquots of antiserum previously determined to precipitate all labeled antigen. Characteristics of the antiserum have been described (16). Excess formalin-fixed staphylococci bearing protein $\mathrm{A}$ was added for $1 \mathrm{~h}$ at $4^{\circ} \mathrm{C}$. Immunoprecipitates were washed, released by boiling in sample buffer, and applied to $7.5 \%$ SDSPAGE under reducing conditions as described by Laemmli (19). Molecular mass markers $(200,000,92,500,68,000,46,000$, and $30,000 \mathrm{D})$ were included on all gels. After electrophoresis, gels were stained with Coomassie Brilliant Blue, destained, impregnated with 2,5-diphenyloxazole and dried for fluorography on Kodak XAR X-ray film (Eastman Kodak Co.).
DNA-mediated gene transfer. Gene transfer followed a previously described modification of the technique of Wigler et al. $(17,20)$. Cosmid DNA $(5 \mu \mathrm{g})$, pBR-TK DNA $(0.5-1.0 \mu \mathrm{g})$, and C3H/HeJ liver DNA (20 $\mu \mathrm{g})$ were incorporated into a calcium phosphate precipitate and applied to $100-\mathrm{mm}$ culture dishes containing $1-2 \times 10^{6}$ cells. Within $48 \mathrm{~h}$, medium was replaced by a selective medium (DME containing $10 \%$ fetal bovine serum, $1.36 \mathrm{mg} / \mathrm{ml}$ hypoxanthine, $17.4 \mu \mathrm{g} / \mathrm{ml}$ aminopterin, and $388 \mu \mathrm{g} / \mathrm{ml}$ thymidine [HAT]). HAT-resistant colonies were isolated and propagated in selective medium.

Southern and Northern blotting. High molecular weight DNA and total cellular RNA were isolated using previously described techniques $(21,22)$. DNA was digested to completion with fourfold excess of restriction enzyme and fractionated by agarose gel electrophoresis. RNA was denatured by heating in formaldehyde and fractionated in agaroseformaldehyde electrophoresis before transfer to nitrocellulose, hybridization to the appropriate radiolabeled cDNA probe, and autoradiography (23).

Assay of $C 2$ hemolytic activity. Reagents were prepared and hemolytic titration specifically for human $\mathrm{C} 2$ activity were conducted according to the method of Rapp and Borsos (24).

\section{Results}

Cloning and chromosomal localization of the murine second component of complement gene. Restriction endonuclease digestion of cosmid DNAs isolated from an $\mathrm{H}-2^{\mathrm{d}}$ murine genomic library (6) followed by Southern blot analysis using as a probe a cDNA encoding a portion of human $\mathrm{C} 2$ ( $\mathrm{pC} 2-6$, reference 25 ) as well as a probe encoding a portion of murine $\mathrm{C} 2$ (kindly provided by Drs. P. Lapre and A. S. Whitehead, Children's Hospital), indicated that the gene encoding murine $\mathrm{C} 2$ was located $5^{\prime}$ to the gene encoding murine factor B (Fig. 1). Cosmid D-9 appeared to span both the $\mathrm{C} 2$ and factor $\mathrm{B}$ genes. Using 5 ' and 3 ' subfragments of the human $\mathrm{C} 2 \mathrm{cDNA}$ as probes, it was possible to show that the murine $\mathrm{C} 2$ gene shares the same $5^{\prime}-3^{\prime}$ orientation as the murine factor $B$ gene. Southern blot analysis of $\mathrm{H}-2^{\mathrm{d}}$ genomic DNA showed co-migrating Bam H1 (6.9 kilobase (kb)), Hind III (4.7 kb), Kpn I (20 kb), and Sac I (14 kb) fragments using the murine $\mathrm{C} 2$ and human factor $\mathrm{B}$ cDNAs as probes (Fig. 2). These probes hybridized to different Xbal fragments $(C 2,5.1 \mathrm{~kb}$; factor $\mathrm{B}, 7.0 \mathrm{~kb})$. An identical hybridization pattern was observed in Southern blots of cosmid D-9 using the same probes (data not shown). The C2 and factor B genes were separated by $<4,500$ base pairs. It was not possible to determine the exact distance between the two genes because a cDNA containing the $5^{\prime}$ end of the murine factor B gene is not currently available. These data are similar to results obtained from studies of cosmids containing the human C2 and factor B genes (4).

Isolation of cosmid clones containing genes encoding human $C 2$ and factor $B$. A human cosmid library was screened using a cDNA encoding human factor B (pBfA28, reference 13) as a probe. Two cosmids, designated $\mathrm{cBf} 1$ and $\mathrm{cBf} 2$ (Fig. 1), were isolated, and contained factor $B$-hybridizing restriction fragments that co-migrated with human genomic factor $B$ restriction fragments on gel electrophoresis (data not shown). These cosmids also contained restriction fragments that hybridized with the human C2 cDNA (data not shown). Neither cosmid contained sequences homologous to a human C4 cDNA. In subsequent experiments, the cosmid DNA encoding the murine $\mathrm{C} 2$ and factor B genes, cosmid D-9, will be referred to as the murine cosmid, and the cosmid DNAs encoding the human $\mathrm{C} 2$ and factor $\mathrm{B}$ genes, cosmids $\mathrm{cBf} 1$ and $\mathrm{cBf} 2$, will be referred to as the human cosmids. 


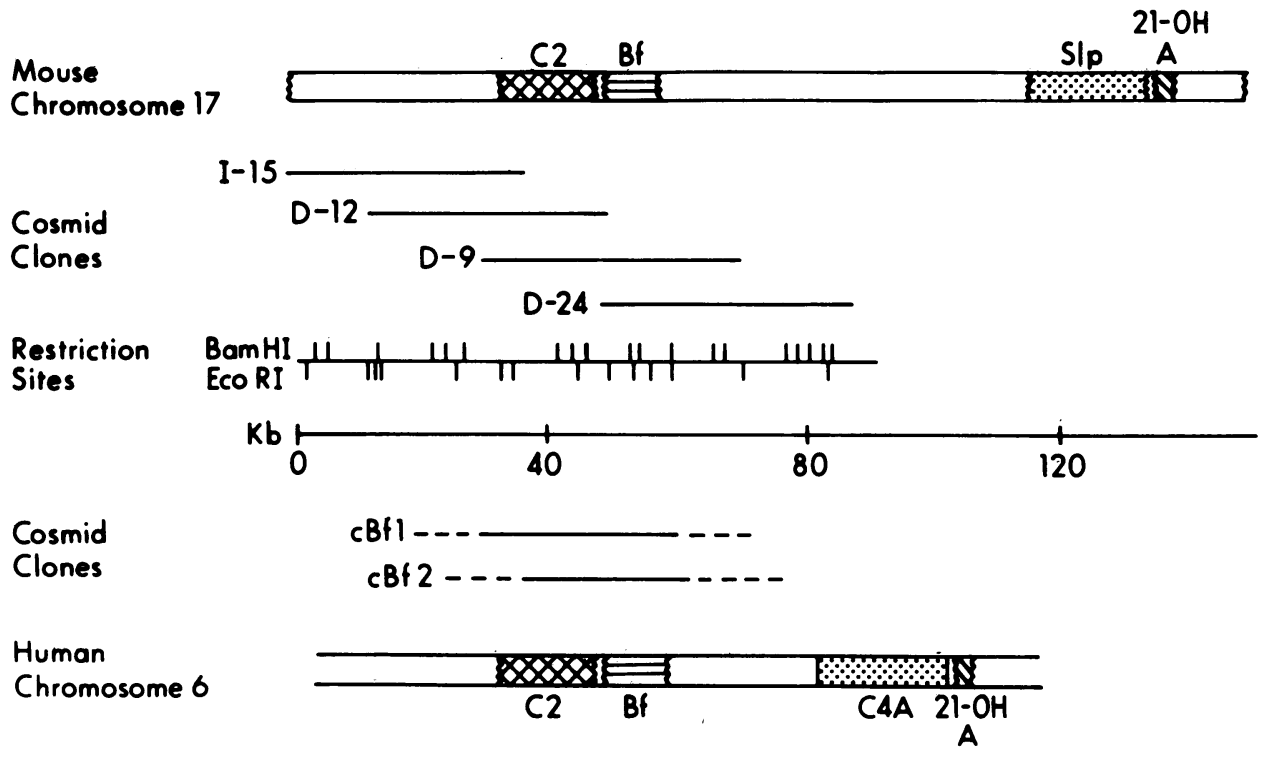

Figure 1. Molecular organization of the murine and human $\mathrm{C} 2$ and factor $B$ genes. Four overlapping murine cosmid clones define the relative location of the murine $\mathrm{C} 2$ and factor $B$ genes. The location of the factor $B$ and Slp genes are described in reference 6 . The location of the 21-hydroxylase gene (21-OH A) is as described in reference 31 . The location of the human genes is taken from references 3 and 32. All genes are transcribed in the same direction, $5^{\prime}$ to $3^{\prime}$ from the left of the figure to the right. The boundaries of the genes have not been determined precisely and are shown by wavy lines. The restriction map of the murine cosmids using BamH1 and EcoR1, as previously described (6), is indicated. The exact extents of cosmids $\mathrm{cBf} 1$ and $\mathrm{CBF} 2$ have not been determined and are indicated by dotted lines. The scale is in $\mathrm{kb}$ pairs.

DNA-mediated gene transfer. In order to examine the expression of $\mathrm{C} 2$ and factor $\mathrm{B}$, the murine cosmid and the human cosmid were co-transfected with the herpes simplex virus thymidine kinase gene into separate $\mathrm{L}$ cell monolayers, and transfectants were selected using HAT medium. More than $75 \%$ of HAT-resistant colonies contained cosmid DNA sequences. By Southern blot analysis, cosmid DNA sequences were present in HAT-resistant colonies in 5-15 copies per cell (data not shown). Identification of factor $B$ and C2 RNA in transfected cells. Factor $B$ mRNA was detected in mouse $L$ cells transfected with cosmid CBfi (human) and in cells transfected with cosmid D9 (murine), appearing as a single band of $\sim 2.5 \mathrm{~kb}$ on Northern blot analysis (Fig. 3). Factor B RNA was not detected in mouse $\mathrm{L}$ cells transfected with the control plasmids (Fig. 3). C2 mRNA was detected in untransfected $\mathrm{L}$ cells and $\mathrm{L}$ cells transfected with the control plasmid, appearing at $\sim 2.6 \mathrm{~kb}$ on Northern blot analysis (Fig. 3) and co-migrating with human liver, human bronchoalveolar macrophage (Fig. 4, lanes 1 and 2), mouse liver,

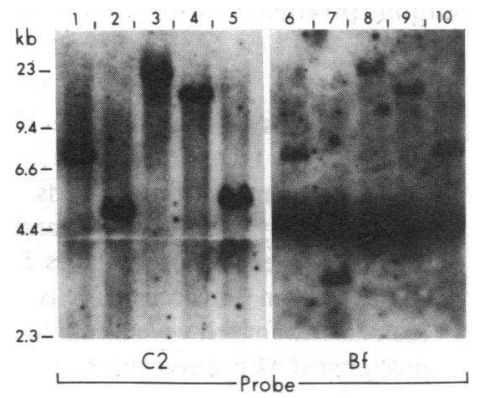

Figure 2. Southern blot analysis of mouse genomic DNA. $15 \mu \mathrm{g}$ of balb/c liver DNA was digested to completion with the indicated restriction enzymes and analyzed by electrophoresis on a $0.8 \%$ agarose gel followed by Southern blot transfer as previously described (6). Duplicate samples were analyzed on the same gel. Gelpurified probes $(0.25 \mu \mathrm{g})$ were labeled with ${ }^{32} \mathrm{P}$ by nick-translation to a specific activity of $2-4 \times 10^{8} \mathrm{cpm} / \mu \mathrm{g}(14)$. Hybridization was as indicated with the $0.9-\mathrm{kb}$ insert of $\mathrm{pC} 2 \mathrm{M} 1$ (lanes $1-5$ ) and the 1.9-kb insert of pBfA28 (6-10). Hybridizing restriction fragments were identified by autoradiography. 1 and 6, digestion with Bam $\mathrm{HI} ; 2$ and 7 , digestion with Hind III; 3 and 8, digestion with Kpn I; 4 and 9, digestion with Sac I; 5 and 10, digestion with Xba I. and mouse peritoneal macrophage $\mathrm{C} 2 \mathrm{mRNA}$ (data not shown). In cells transfected with the murine cosmid, there appeared to be several fold more RNA hybridizing with the $\mathrm{C} 2 \mathrm{cDNA}$ probe than in $\mathrm{L}$ cells transfected with the control plasmid. An additional and predominant $\mathrm{C} 2 \mathrm{mRNA}$ of $\sim 2.0 \mathrm{~kb}$ was detected only in L cells transfected with cosmid DNA containing the human genes (Figs. 3 and 4).

Biosynthesis and secretion of factor $B$ and $C 2$ by transfected cells. Transfected $\mathrm{L}$ cells were radiolabeled and products analyzed by immunoprecipitation, SDS-PAGE, and fluorography. Cells transfected with the murine cosmid synthesized and secreted factor B (Fig. 5, lanes 1 and 2). Two polypeptides of $\sim 87,000$

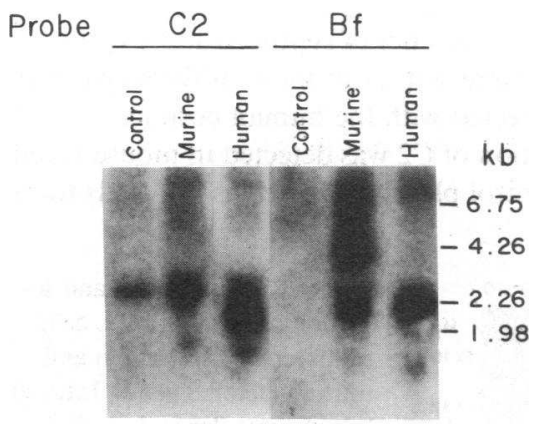

Figure 3. Northern blot analysis of RNA isolated from transfected $L$ cells. Total cellular RNA was isolated from $\sim 1 \times 10^{7} \mathrm{~L}$ cells. $20 \mu \mathrm{g}$ of the indicated RNAs were subjected to electrophoresis in agarose-formaldehyde gels and transferred to nitrocellulose as described (23). ${ }^{32} \mathrm{P}$ labeled Hind III fragments of lambda DNA were included as relative size markers on each gel. Right and left panels are taken from replicate gels. The left panel was hybridized with $0.1 \mu \mathrm{g}$ of human factor B cDNA (pBfA28) and the right panel with $0.1 \mu \mathrm{g}$ of human C2 cDNA (pC2-6) nick-translated to a specific activity of $4 \times 10^{8} \mathrm{cpm} / \mu \mathrm{g}$. Washing was at $50^{\circ} \mathrm{C}$ in $0.2 \times \mathrm{SSC}(30 \mathrm{mM} \mathrm{NaCl}, 3 \mathrm{mM}$ sodium citrate, and $0.1 \%$ SDS). Autoradiography was conducted for $12 \mathrm{~h}$ at $-70^{\circ} \mathrm{C}$ using Kodak XAR film (Eastman Kodak Co.) with an intensifying screen. 


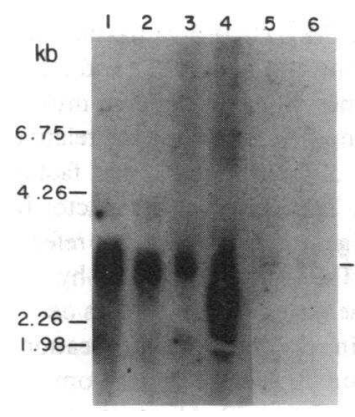

Figure 4. Northern blot analysis of RNA isolated from transfected $L$ cells compared with RNA isolated from cells in primary culture. Total cellular RNA was isolated and subjected to agarose-formaldehyde electrophoresis as described above. RNA from humán liver (lane 1), human bronchoalveolar macrophages (2), L cells transfected with the murine cosmid (3), and $L$ cells transfected with the human cosmid (4) were compared wwith L cells transfected with the control plasmid

(5) and L cells alone (6) and hybridized with the human C2 cDNA as described in Fig. 3. The $\sim 2.6 \mathrm{~kb} \mathrm{C2}$ RNA is indicated.

and $\sim 89,000 \mathrm{D}$ were detected in the intracellular contents, and two polypeptides of $\sim 90,000$ and $\sim 92,000 \mathrm{D}$ were secreted, co-migrating with factor B polypeptides synthesized and secreted by murine peritoneal macrophages (Fig. 5, lanes 3 and 4). Cells transfected with the human cosmid synthesized factor B as a single polypeptide, $\sim 90,000 \mathrm{D}$ in apparent size, and secreted a single $\sim 92,000$-D factor B polypeptide (Fig. 5, lanes 5 and 6). Single factor B polypeptides of the same apparent size were also synthesized and secreted by human hepatoma-derived hepatocytes (Fig. 5, lanes 7 and 8). There was no evidence for synthesis and secretion of factor $B$ by mouse $L$ cells transfected with the control plasmid (Fig. 5, lanes 9 and 10).

The kinetics of synthesis and secretion of factor B by L cells transfected with the human cosmid (Fig. $6 \mathrm{~A}$ ) were compared with those of $\mathrm{L}$ cells transfected with the murine cosmid (Fig. 6 $B$ ) in pulse-chase experiments. The single, $\sim 90,000-D$ intracellular factor B polypeptide synthesized by $L$ cells transfected with the human cosmid began to disappear at 30-60 min of the chase period, coincident with its appearance in the fully glycosylated $\sim 92,000 \mathrm{D}$ form in the intra- and extracellular contents (Fig. $6 \mathrm{~A}$ ). Factor B is secreted with similar kinetics over the remaining $360 \mathrm{~min}$ of the chase period. Two intracellular factor $B$ polypeptides are synthesized by $L$ cells transfected with the murine cosmid (Fig. $6 \mathrm{~B}$ ). Kinetics of synthesis and secretion of these two polypeptides were similar to those of the single polypeptide in L cells transfected with the human cosmid.

Synthesis and secretion of $\mathrm{C} 2$ was detected in mouse $\mathrm{L}$ cells transfected with the control plasmids as well as in $\mathrm{L}$ cells trans-

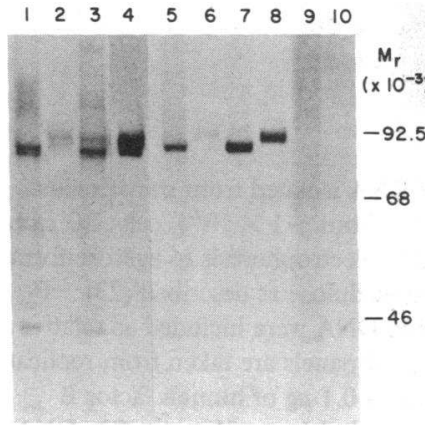

Figure 5. Biosynthesis and secretion of factor B by $L$ cells transfected with human and murine factor B genes. Intracellular lysates (lanes $1,3,5,7$, and 9) and extracellular media $(2,4,6,8$, and 10$)$ of transfected $L$ cells radiolabeled for 4 $\mathrm{h}$ were immunoprecipitated with goat anti-human factor $B$ for SDS-PAGE and fluorography next to molecular mass markers. $L$ cells transfected with murine cosmid ( 1 and 2$)$ are compared with those transfected with human cosmid ( 5 and 6 ), to mouse peritoneal macrophages ( 3 and 4 ), and to human hepatoma-derived hepatocytes (7 and 8 ). Lysates and media of $\mathrm{L}$ cells transfected with the control plasmid are also included $(9$ and 10$)$.

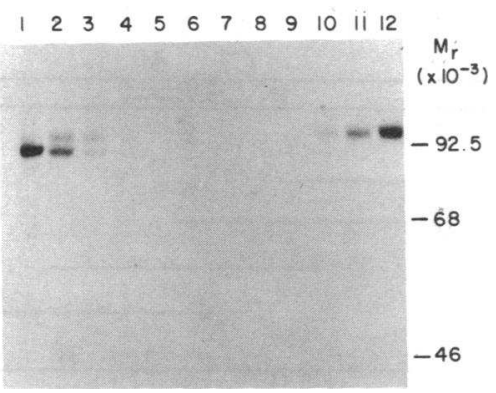

B

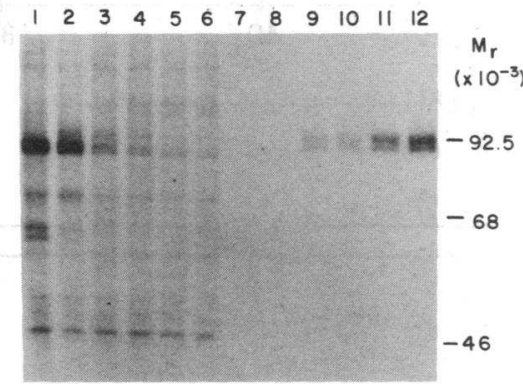

Figure 6. Kinetics of synthesis and secretion of factor B by transfected $\mathrm{L}$ cells. $(A) \mathrm{L}$ cells transfected with human cosmid. L cells were labeled for $0.5 \mathrm{~h}$ with L- $\left[{ }^{35} \mathrm{~S}\right]$ methionine and chased with unlabeled methionine for intervals up to $6 \mathrm{~h}$. Cells were then solubilized, supernatants and lysates immunoprecipitated and analysed by SDS-PAGE and fluorography. Lanes 1-6 contain cell lysates and 7-12 contain extracellular media from chase time points $0,0.5,1,2,4$, and $6 \mathrm{~h}$. (B) $\mathrm{L}$ cells transfected with murine cosmid. Exactly as in $A$. Faster migrating radiolabeled bands were nonspecific and not reproduced in other experiments.

fected with the human and murine cosmids (Fig. 7). The principle intracellular form of C2 was $86,000 \mathrm{~mol} \mathrm{wt}$, with additional faster migrating $C 2$. polypeptides at $84,000,70,000,67,000$, and $65,000 \mathrm{D}$ similar to the additional lower molecular weight cellassociated forms of $\mathrm{C} 2$ protein observed in human hepatomaderived hepatocytes (Fig. 7, lanes 7 and 8, reference 16). C2 was secreted by $L$ cells transfected with the human and murine cosmid and control plasmids as a polypeptide with apparent size of 94,000 D (Fig. 7, lanes 2, 4, and 6). Another $\sim 70,000 \mathrm{D}$ form of $\mathrm{C} 2$ protein was also seen in the extracellular compartment and thought to be the $\mathrm{C} 2 \mathrm{a}$ fragment. All the $\mathrm{C} 2$ polypeptides, intracellular and extracellular, produced by mouse $L$ cells

Figure 7. Biosynthesis and secretion of $C 2$ by $L$ cells transfected with human and murine cosmids. Intracellular lysates (lanes 1,3 , and

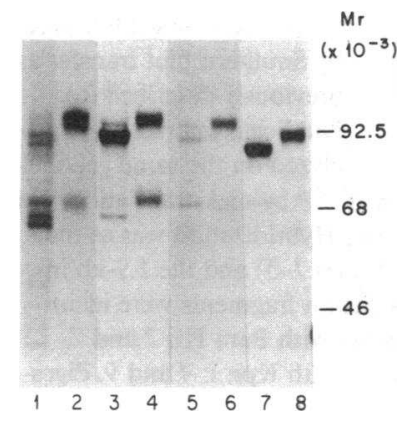
$5)$ and extracellular media (lanes 2 4 , and 6) from transfected $L$ cells radiolabeled for $4 \mathrm{~h}$ were immunoprecipitated with sheep anti-human C2 for SDS-PAGE and fluorography next to molecular mass markers. $L$ cells transfected with human cosmid ( 1 and 2$)$, murine cosmid ( 3 and 4), control plasmid (5 and 6) are compared with human hepatoma-derived hepatocytes (7 and 8$)$. 
were slightly slower in migration than the corresponding polypeptides identified in the HepG2 cells. Extracellular fluid from L cells transfected with the human cosmid was hemolytically active in the human $\mathrm{C} 2$ hemolytic assay (Fig. 8). Culture fluid from $L$ cells transfected with the murine cosmid or control plasmid (Fig. 8) or culture fluid from murine peritoneal macrophages in primary culture (data not shown) did not produce hemolysis in this assay.

\section{Discussion}

Structural and functional similarities between factor B and C2 have been attributed to primary sequence homology and have suggested evolution by gene duplication. In fact, recent molecular maps have indicated that the human factor B and C2 genes are less than $\sim 2,000$ base pairs apart in the genome of the Class III region of the $\mathrm{MHC}(4,5)$. Nevertheless, failure to demonstrate cross-hybridization of the two genes, even at very low stringency, indicates a substantial degree of nucleotide sequence divergence (26). In addition to the nucleotide sequence differences implied by the cross-hybridization experiments, differences in the regulation of $\mathrm{C} 2$ and factor B by hepatocytes and mononuclear phagocytes from several species have also been identified $(7-11,16)$.

In this study, we have demonstrated that the murine genes encoding $\mathrm{C} 2$ and factor $\mathrm{B}$ are very closely linked within the class III region of the murine $\mathrm{MHC}$, with organization similar to that in man. Expression of human and murine factor $B$ and human $\mathrm{C} 2$ was demonstrated in a murine fibroblast cell line transfected with cosmid DNA containing these genes. Factor B RNA was detected in cells transfected with the human and murine cosmid but not in cells transfected with the control plasmid. Biosynthesis and secretion of factor B was detected in cells transfected with the human and murine cosmids by incorporation of a radiolabeled amino acid precursor into newly synthesized protein. Expression of the transferred human $\mathrm{C} 2$ gene was demonstrated by a distinct 2.0-kb C2 RNA species (Figs. 3 and 4) and functional activity of the transfected cell culture fluid in the human $\mathrm{C2}$ hemolytic assay (Fig. 8). L cells transfected with the murine cosmid contained higher steady state levels of C2 RNA than those transfected with the control plasmid; however, expression of the transferred murine $\mathrm{C} 2$ gene could not be further distinguished from endogenous $\mathrm{C} 2$ expressed in the control transfected cells because of the absence of polymorphic differences in $\mathrm{C} 2$ between the donor $\mathrm{H}-2^{\mathrm{d}}$ mice and the recipient $\mathrm{H}-2^{\mathrm{k}} \mathrm{L}$ cells.

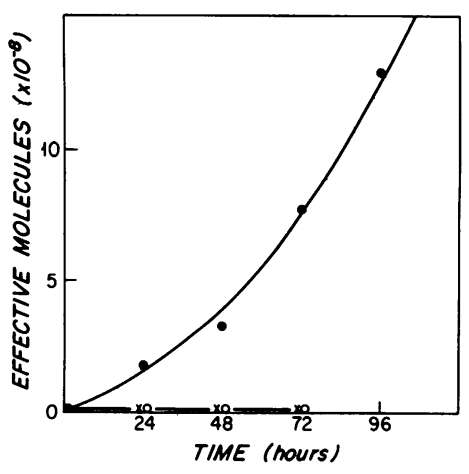

Figure 8. Secretion of hemolytically active $\mathrm{C} 2$ by transfected L cells. Cell culture fluid from $\mathrm{L}$ cells transfected with human cosmid (closed circles), $\mathrm{L}$ cells transfected with murine $\operatorname{cosmid}(X)$, and $L$ cells transfected with the control plasmid (open circles) were tested in the human $\mathrm{C} 2$ hemolytic assay. For this experiment, cell culture fluid was collected at the indi-

cated time intervals, and the monolayers resuspended in fresh culture fluid.
In addition to demonstrating that $\mathrm{C} 2$ and factor $\mathrm{B}$ can be expressed by $\mathrm{L}$ cells after DNA-mediated gene transfer, differences in the way these two closely linked complement genes are expressed have also been identified. Untransfected, or control transfected, $L$ cells synthesize and secrete $C 2$, but not factor $B$. While we have previously shown that the fourth component of complement (C4) is not expressed by untransfected L cells (17), expression of $\mathrm{C} 2$ by $\mathrm{L}$ cells has not been previously addressed. Nevertheless, $\mathrm{C} 2$ is not unique in this respect since others have shown that the third component of complement (C3) is secreted by a number of established fibroblast cell lines $(27,28)$.

After transfection of the human factor B and C2 genes into L cells on the same cosmid, both genes were expressed. Whereas factor B was synthesized, processed, and secreted with extraordinary fidelity, C2 was transcribed, or the transcript modified, in an altered form as seen in Northern blot analysis (Figs. 3 and 4). The nature of the differences between the $2.0-\mathrm{kb} \mathrm{C} 2$ hybridizing sequences recovered from cells transfected with the human cosmid and the usual 2.6-kb C2 mRNA obtained from human and murine hepatocytes and macrophages is not known. Differences in the $2.0-\mathrm{kb}$ RNA could reside in the untranslated region. It is also possible that this apparently smaller RNA encodes $\mathrm{C} 2$ in an alternative polypeptide form, which is similar to the previously reported cell associated forms of C2 (16).

Differences in the expression of other closely linked genes has also been demonstrated before and after DNA-mediated gene transfer. Transcription of an alpha globin gene was different from that of a beta globin gene despite transfer into mouse erythroleukemia cells on the same plasmid (29). In that case, regulation of expression was attributed to sequences within the individual structural genes. Further studies with cosmid DNAs containing the $\mathrm{C} 2$ and factor $\mathrm{B}$ genes individually will be necessary to localize sequences regulating the expression of $\mathrm{C} 2$ and factor B in transfected $L$ cells. It is still possible that a single promoter on the $5^{\prime}$ side of the $\mathrm{C} 2$ gene, individual promoters on the $5^{\prime}$ sides of the $\mathrm{C} 2$ and factor $\mathrm{B}$ genes, or structural elements control the expression of $\mathrm{C} 2$ and factor $\mathrm{B}$.

Several additional features of $\mathrm{C} 2$ and factor $\mathrm{B}$ expression have been identified in these experiments. Although not identical, multiple intracellular forms of $\mathrm{C} 2$ protein in transfected $\mathrm{L}$ cells are similar to multiple forms of $\mathrm{C} 2$ synthesized by human liver (16). The multiple intracellular forms of $\mathrm{C} 2$ identified in human liver have different fates, one form being secreted and two forms remaining cell associated. These forms are derived from distinct primary translation products and presumably distinct RNA species, as there is only a single C2 gene (16). With these considerations in mind, further studies of the relationship between the additional distinct $\mathrm{C} 2$ RNA and the multiple intracellular forms of $\mathrm{C} 2$ in L cells transfected with the human cosmid DNA will be important.

An interspecies variation between murine and human factor B was also identified. Factor B was synthesized and secreted as two polypeptides by L cells transfected with the murine cosmid, but as a single polypeptide by $L$ cells transfected with the human cosmid. This difference was also observed for biosynthesis of factor B by murine cells (peritoneal macrophages) (30) in primary culture compared with that of human cells (hepatoma-derived hepatocytes). Since this variation in the way factor B is translated and processed is preserved when murine and human factor B genes are expressed in the same cell, the variation must reside in the factor B genes themselves, rather than in differential processing in the human or murine cells. 
These experiments, therefore, indicate that $\mathrm{C} 2$ and factor $\mathrm{B}$ are expressed by mouse L cells after DNA-mediated gene transfer, and that intracellular processing of these complement proteins is reproduced with extraordinary fidelity by the $\mathrm{L}$ cells. Further analysis of $\mathrm{C} 2$ and factor $\mathrm{B}$ in this system in comparison with human and murine hepatocytes and macrophages will allow a greater understanding of their differential regulation, both at the level of RNA metabolism and at the level of posttranslational processing and secretion.

\section{Acknowledgments}

The authors are indebted to Claudia S. Leonard for technical assistance, Dr. Shu-hei Takemura for performing hemolytic assays, and Helen Hourihan for secretarial assistance.

This work was supported by U. S. Public Health Service grants AM07114, AI18436, AI19148, HD17461, AI20032, AI21157, HL32361, and $\mathrm{AM} 13230$.

\section{References}

1. Reid, K. B. M., and R. R. Porter. 1981. The proteolytic activation systems of complement. Annu. Rev. Biochem. 50:433-464.

2. Colten, H. R. 1982. Biosynthesis of the MHC-linked complement proteins (C2, C4 and Factor B) by mononuclear phagocytes. Mol. Immunol. 19:1279-1285.

3. Alper, C. A. 1981. Complement and the MHC. In The Role of the Major Histocompatibility Complex in Immunobiology. M. E. Dorf, editor. Garland Press, New York. 173-220.

4. Carroll, M. C., R. D. Campbell, D. Bentley, and R. R. Porter. 1984. A molecular map of the major histocompatibility class III region of man linking the complement genes $\mathrm{C} 4, \mathrm{C} 2$ and factor B. Nature (Lond.). 307:237-241.

5. Carroll, M. C., T. Belt, A. Palsdottir, and R. R. Porter. 1984. Structure and organization of the C4 genes. Philos. Trans. R. Soc. Lond. B Biol. Sci. 306:379-388.

6. Chaplin, D. D., D. E. Woods, A. S. Whitehead, G. Goldberger, H. R. Colten, and J. G. Seidman. 1983. Molecular map of the murine S region. Proc. Natl. Acad. Sci. USA. 80:6947-6951.

7. Sackstein, R., and H. R. Colten. 1984. Molecular regulation of MHC class III (C4 and Factor B) gene expression in mouse peritoneal macrophages. J. Immunol. 130:834-838.

8. Bentley, C., D. Bitter-Suermann, U. Hadding, and V. Brade. 1977. In vitro synthesis of factor $B$ of the alternative pathway of complement by mouse peritoneal macrophages. Eur. J. Immunol. 6:393-398.

9. Newell, S. L., and J. P. Atkinson. 1983. Biosynthesis of C4 by mouse peritoneal macrophages. II. Comparison of $\mathrm{C} 4$ synthesis by resident and elicited cell populations. J. Immunol. 130:834-838.

10. Cole, F. S., E. E. Schneeberger, N. A. Lichtenberg, and H. R. Colten. 1982. Complement biosynthesis in human breast milk macrophages and blood monocytes. Immunology. 46:429-441.

11. Cole, F. S., W. J. Matthews, T. H. Rossing, D. J. Gash, N. A. Lichtenberg, and J. E. Pennington. 1983. Complement biosynthesis by human bronchoalveolar macrophages. Clin. Immunol. Immunopathol. 27:153-159.

12. Hanahan, D., and M. Meselson. 1980. Plasmid screening at high colony density. Gene (Amst.) 10:63-67.

13. Woods, D. E., A. Markham, A. Ricker, G. Goldberger, and H. R. Colten. 1982. Isolation of cDNA clones for the human complement protein factor B, a class III major histocompatibility complex gene product. Proc. Natl. Acad. Sci. USA. 80:4464-4468.

14. Rigby, P., M. Diekmann, C. Rhodes, and P. Berg. 1977. Labeling deoxyribonucleic acid to high specific activity in vitro by nick translation with DNA Polymerase I. J. Mol. Biol. 113:237-251.

15. Ish-Horowicz, D., and J. Burke. 1981. Rapid and efficient cosmid cloning. Nucleic Acid Res. 9:2989-2998.

16. Perlmutter, D. H., F. S. Cole, G. Goldberger, and H. R. Colten. 1984. Distinct primary translation products from human liver RNA give rise to secreted and cell-associated forms of complement protein C2. $J$. Biol. Chem. 259:10380-10385.

17. Chaplin, D. D., R. Sackstein, D. H. Perlmutter, J. Weis, J. Coligan, H. R. Colten, and J. G. Seidman. 1984. Expression of hemolytically active murine fourth component of complement in transfected L-cells. Cell. 37:569-576.

18. Roberts, B. E., and B. M. Patterson. 1973. Effect of translation of tobacco mosaic virus RNA and rabbit globin 9S RNA in a cell-free system from commercial wheat germ. Proc. Natl. Acad. Sci. USA. 70: 2330-2334.

19. Laemmli, U. K. 1970. Cleavage of structural proteins during the assembly of the head of bacteriophage T4. Nature (Lond.). 227:680-685.

20. Wigler, M., S. Silverstein, L. S. Lee, A. Pellicer, Y. Cheng, and R. Axel. 1977. Transfer of purified herpes thymidine kinase gene to cultured mammalian cells. Cell. 11:223-232.

21. Blin, N., and D. Stafford. 1976. A general method for isolation of high molecular weight DNA from eukaryotes. Nucleic Acid Res. 3: 2303-2309.

22. Chirgwin, J., G. Prybyla, R. MacDonald, and W. Rutter. 1979. Isolation of biologically active ribonucleic acid from sources enriched in ribonuclease. Biochemistry. 18:5294-5299.

23. Thomas, P. 1980. Hybridization of denatured RNA and small DNA fragments transferred to nitrocellulose. Proc. Natl. Acad. Sci. USA. 77:5201-5205.

24. Rapp, H. J., and T. Borsos. 1970. Molecular Basis of Complement Action. Appleton-Century Crofts, New York.

25. Bentley, D. R., and R. R. Porter. 1984. Isolation of a cDNA clone for human complement component C2. Proc. Natl. Acad. Sci. USA. 81:1212-1216.

26. Woods, D. E., M. D. Edge, and H. R. Colten. 1984. Isolation of a complementary DNA clone for the human complement protein $\mathrm{C} 2$ and its use in the identification of a restriction fragment length polymorphism. J. Clin. Invest. 74:634-638.

27. Senger, D. R., and R. O. Hynes. 1978. C3 component of complement secreted by established cell lines. Cell. 15:375-384.

28. Whitehead, A. S., R. Sim, and W. Bodmer. 1981. A monoclonal antibody against human complement component $\mathrm{C} 3$ : the production of C3 by human cells in vitro. Eur. J. Immunol. 11:140-146.

29. Charnay, P., R. Treisman, P. Mellon, M. Chao, R. Axel, and T. Maniatis. 1984. Differences in human alpha- and beta-globin gene expression in mouse erythroleukemia cells: role of intragenic sequences. Cell. 38:251-263.

30. Sackstein, R., H. R. Colten, and D. E. Woods. 1984. Phylogenetic conservation of a class III major histocompatibility complex antigen, factor B: isolation and nucleotide sequencing of mouse factor B cDNA clones. J. Biol. Chem. 258:14693-14697.

31. White, P. C., D. D. Chaplin, J. H. Weis, B. Dupont, M. New, and J. G. Seidman. 1984. Two steroid 21-hydroxylase genes are located in the $\mathrm{S}$ region of the mouse. Nature (Lond.). 312:465-467.

32. Carroll, M. C., R. D. Campbell, and R. R. Porter. 1985. Mapping of steroid 21-hydroxylase genes adjacent to complement component $\mathrm{C4}$ genes in HLA, the major histocompatibility complex in man. Proc. Natl. Acad. Sci. USA. 82:521-525. 